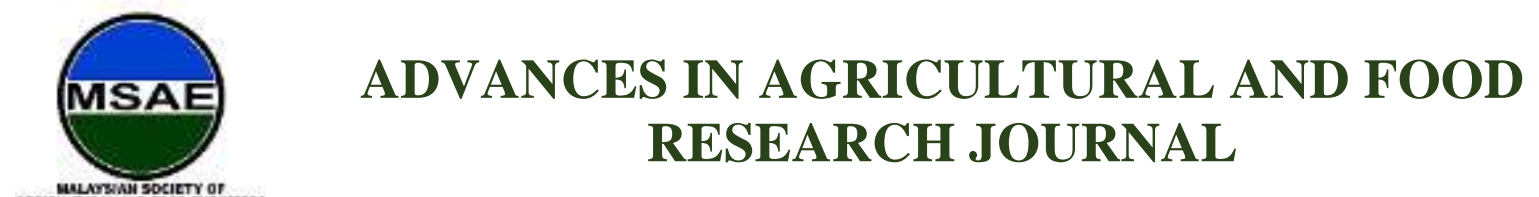

HHPUBLISHER

Original Research Article

\title{
Anaerobic Co-digestion of Pineapple Wastes with Cow Dung: Effect of Different Total Solid Content on Bio- methane Yield
}

\author{
Adila Fazliyana Aili Hamzah ${ }^{1 *}$, Muhammad Hazwan Hamzah ${ }^{1,2}$, Fauzan Najmi Ahmad Mazlan ${ }^{1}$, Hasfalina \\ Che Man ${ }^{1,2}$, Nur Syakina Jamali ${ }^{3}$, Shamsul Izhar Siajam ${ }^{3}$ \\ ${ }^{1}$ Department of Biological and Agricultural Engineering, Faculty of Engineering, Universiti Putra Malaysia, \\ 43400 UPM Serdang, Selangor, Malaysia \\ ${ }^{2}$ Smart Farming Technology Research Centre, Faculty of Engineering, Universiti Putra Malaysia, 43400 UPM \\ Serdang, Selangor, Malaysia \\ ${ }^{3}$ Department of Chemical and Environmental Engineering, Faculty of Engineering, Universiti Putra Malaysia, \\ 43400 UPM Serdang, Selangor, Malaysia, syakina@upm.edu.my, shamizhar@upm.edu.my
}

*Corresponding author: Muhammad Hazwan Hamzah, Department of Biological and Agricultural Engineering, Faculty of Engineering, Universiti Putra Malaysia, 43400 UPM Serdang, Selangor, Malaysia; hazwanhamzah@upm.edu.my

\begin{abstract}
The abundance of agricultural wastes produced from pineapple processing and livestock industries has resulted in the difficulties of disposing of a large amount of waste. Anaerobic digestion is a way to reduce waste and generate renewable energy sources including biogas. In this study, pineapple waste is co-digested with cow dung in batch experiments under mesophilic temperature at $38 \pm 1{ }^{\circ} \mathrm{C}$ at a working volume of $100 \mathrm{ml}$ in 125 $\mathrm{ml}$ serum bottle. The effects of the total solid on methane yields are investigated at a different substrate ratio. The batch study is conducted at 3 different total solid which are $12 \%, 20 \%$ and $28 \%$ and at three different substrate ratio cow dung to pineapple waste (CD: PW) (1:1, $1: 2$ and 1:3). Daily biogas collection for $28 \%$ total solid at $1: 1$ ratio results in the highest cumulative biogas production of $313 \mathrm{ml}$, followed by $28 \%$ total solid at 1:3 ratio with $246 \mathrm{ml}$ biogas yield. The highest methane yield is achieved at $12 \%$ total solid with a 1:2 ratio (17.19 $\mathrm{CH}_{4} / \mathrm{g}$ VS). Results show that at $12 \%$ total solid produces the highest methane yield at all ratios compared to other total solid percentages. Moreover, methane yield decreases as the total solid percentage increases from $12 \%$ to $28 \%$. Overall, the production of methane from pineapple wastes co-digested with cow dung is proven to be a good strategy to minimise solid wastes.
\end{abstract}

Keywords: Biogas; co-digestion; cow dung; methane; pineapple; total solid

Received: $8^{\text {th }}$ August 2020

Accepted: $10^{\text {th }}$ September 2020

Citation: Aili Hamzah AF, Hamzah $\mathrm{MH}$, Ahmad Mazlan FN, et al. Anaerobic co-digestion of pineapple wastes with cow dung: Effect of different total solid content on bio-methane yield.

Published: $30^{\text {th }}$ September 2020 Adv Agri Food Res J 2020; 1(1): a0000109. https://doi.org/10.36877/aafrj.a0000109 


\section{Introduction}

Malaysians generated about 38,142 tons of waste daily in 2018 according to The Star Online and there was a tremendous upsurge in the amount of waste generated in Malaysia in 2018 compared to 19,000 tons waste per day in 2005 in which $44.5 \%$ of them were food waste (Chu, 2019). Through anaerobic digestion, renewable resources especially food waste can be utilised as energy and nutrient. In an anaerobic environment, anaerobic digestion process works by decomposing the organic matter by microbes and produces $50-75 \%$ methane $\left(\mathrm{CH}_{4}\right)$, $19-34 \%$ carbon dioxide $\left(\mathrm{CO}_{2}\right)$ and less than $1 \%$ biohydrogen $\left(\mathrm{H}_{2}\right)$ (Elina, 2016; Jehan et al., 2017). During anaerobic digestion, through the metabolic action of methanogenic bacteria, wastes are converted biochemically into methane. The reactions are carried out by various groups of microbes at four different stages named hydrolysis, acidogenesis, acetogenesis and methanogenesis (Deressa et al., 2015; Mata-Alvarez et al., 2000; Ogunleye et al., 2016).

Nowadays, there are few methods that are subjected to anaerobic digestion: singlephase digestion, two-phase digestion, dry fermentation and co-digestion (Deressa et al., 2015). Three major issues or difficulties have been reported, namely; the effect operational factors, the nutritional imbalance and lack of diversified microorganisms via direct utilisation of substrates or mono-substrates in anaerobic digestion (Hagos et al., 2017). Here, it is suggested that the co-digestion process can be performed to reduce the aforementioned problem, like incorporating agricultural by-products with livestock manure. Several lines of evidence have established that co-digestion is an economically feasible and promising technology in terms of good synergism in the digestion reactor and the ability to improve stability of the process, as well as to improve the biogas production rates (Astals et al., 2013; Giuliano, 2013; Mata-Alvarez et al., 2000). Anaerobic digestion is often categorised based on total solids (TS) content classes. Three of the foremost classes based on substrate total TS content - wet for TS lower than 15\%; dry for TS lower than 25\%; and solid-state operated at up to 40\% TS content (Abbassi-Guendouz et al., 2012; Rabii et al., 2019; Yi et al., 2014).

In the pineapple sector, a lot of agricultural waste from pineapple is produced from various harvesting activities (Chakravarty, 2016; Chan, 2000). Currently, according to Rani and Nand (2004), lack of the appropriate method of managing these wastes has become an environmental concern. Converting pineapple wastes into value-added products is one of the promising ways to handle these wastes without destroying the environment (Khai et al., 2014; Maneeintr et al., 2018). Biogas can be produced from peel, core, pulp and crown of pineapple waste, but the amount of nitrogen in these wastes is insufficient to produce a high amount of biogas. A high amount of carbohydrates in pineapple wastes can be used as a carbon source 
for microbial fermentation to produce bio-methane (Khai et al., 2014). Livestock such as cows and buffaloes produce lots of manure and most of the manure ends up as waste. Livestock manure is the main organic waste that contains a high quantity of nitrogen $(\mathrm{N})$ and phosphorus $(\mathrm{P})$, a high percentage of these substances causes nutrient imbalance and failure to properly manage these wastes leads to environmental pollution (Chakravarty, 2016; Deressa et al., 2015). Bacteria found in cow dung are known to produce a high yield of methane gas (Gupta et al., 2016). According to Neshat et al. (2017), facultative and obligative bacteria are responsible for hydrolysis and acidogenesis and several bacterial genera including Corynebacterium, Lactobacillus, Escherichia coli and Actinomyces were isolated from an anaerobic digester.

Lignocellulosic wastes are ineffective to be used as the sole substrate and hard to digest due to their complex structure that hinders their biodegradability. While manure contains useful microorganisms that can enhance biological activity and about 10 pounds of nitrogen were found in per ton of cow dung (Neshat et al., 2017). However, the carbon insufficiency in cow dung cannot completely fulfil the anaerobic digestion requirements. Temperature is one of the important parameters in anaerobic co-digestion. Thus, it has been suggested to be incorporated with carbon-rich wastes. Higher operational temperature requires higher energy demand and that makes mesophilic temperature preferable compared to thermophilic (Alemahdi et al., 2015). The mesophilic temperature should be maintained at $20^{\circ} \mathrm{C}$ to $40^{\circ} \mathrm{C}$. Hydraulic retention time, total solid (TS), volatile solids (VS), initial cultivation $\mathrm{pH}$, temperature, $\mathrm{C} / \mathrm{N}$ ratio and the ratio of pineapple waste to cow dung are some of the common operational parameters that need to be considered when operating anaerobic digester. To ensure high biogas yield, optimisation of these parameters is necessary, but it depends on the type of waste and operation used. Thus, all of these facts suggest for us to optimise the biogas production process from pineapple waste and cow dung using anaerobic co-digestion in mesophilic condition but due to several limitations, only TS factor is chosen as a preliminary study. The current study aims at investigating the effect of TS added in anaerobic co-digestion of pineapple waste with cow dung at different ratios. Hence, incorporating lignocellulosic materials such as pineapple waste and nitrogen-rich waste like cow dung has been seen as a good strategy in managing waste.

\section{Materials and Methods}

\subsection{Substrate Preparation}

The wastes of Sarawak pineapple were collected from sundry supermarkets around Serdang, Selangor area. The pineapple wastes consisting of pulp, core, peel and crown were ground using an electric blender. The cow dung was collected from Ladang 16 at UPM, Selangor. The cow dung and pineapple wastes were stored at $4{ }^{\circ} \mathrm{C}$ and later used as substrates 
for anaerobic co-digestion. The substrates were first characterised on their total solid (TS), volatile solids (VS), carbon (C) and nitrogen content $(\mathrm{N})$ and $\mathrm{pH}$. The carbon and nitrogen were analysed by using CHN628 Series Carbon, Hydrogen, Nitrogen Determinator (LECO, United States) and the values were used to determine the $\mathrm{C} / \mathrm{N}$ ratio of the substrate. Meanwhile, TS and VS were conducted based on the standard method (APHA, 1998). Then, the $\mathrm{pH}$ of the substrates was measured using pH5SS Spear pH Tester (IONIX, Singapore).

\subsection{Experimental Setup}

The anaerobic co-digestion experiment was conducted at $100 \mathrm{ml}$ working volume with $25 \mathrm{ml}$ headspace in $125 \mathrm{ml}$ serum bottles as shown in Figure 1. Pure nitrogen gas was flushed into the serum bottles for 2 minutes to remove oxygen traces as well as to ensure the anaerobic condition and the bottles were enclosed with rubber stoppers. Co-digestion was conducted at mesophilic temperature $\left(38 \pm 1^{\circ} \mathrm{C}\right)$ in water bath WNB 45 (Memmert, Germany) for 30 days. The gas was collected for 30 days to observe the difference of gas produced in each day. The water displacement method was used to measure cumulative biogas production (Jehan et al., 2017). Abbassi-Guendouz et al. (2012) stated that the threshold value of the TS solid of the feedstock is $30 \%$ since the methanogenic activity was strongly inhibited above that value. Meanwhile Fernández et al. (2008) observed that the reactor had significantly high performance when TS content was adjusted to $20 \%$. Ardaji et al. (2016) observed that biogas production increased when TS increased from 5 to $25 \%$. Thus, this study was conducted at TS at $12 \%$ to $28 \%$. The bottles containing the mixture of pineapple waste and cow dung were at 3 different ratio CD: PW of 1:1, 1:2 and 1:3, respectively. The pineapple waste slurry was first diluted to 3 different total solids (TS) of $12 \%, 20 \%$ and $28 \%$ of pineapple waste added using distilled water (Abbassi-Guendouz et al., 2012; Ardaji et al., 2016; Fernández et al., 2008). The initial $\mathrm{pH}$ of both substrates was low; the final $\mathrm{pH}$ after mixing both substrates was still insufficient to be maintained around the optimal $\mathrm{pH}$. Thus, the $\mathrm{pH}$ of substrates was adjusted to $7 \pm 1.0$ using sodium hydroxide $(\mathrm{NaOH})$ (Jehan et al., 2017). In order to produce methane and biogas effectively, it is crucial to maintain $\mathrm{pH}, \mathrm{C} / \mathrm{N}$ ratio and temperature at the optimal condition to provide better growth conditions for methanogenic bacteria. Hence, $\mathrm{pH}$ value must be maintained at 6.5 to 8.0 (Ogunleye et al., 2016; Sibiya et al., 2014). The experiments were triplicate, and biogas was collected daily and its composition was analysed. 


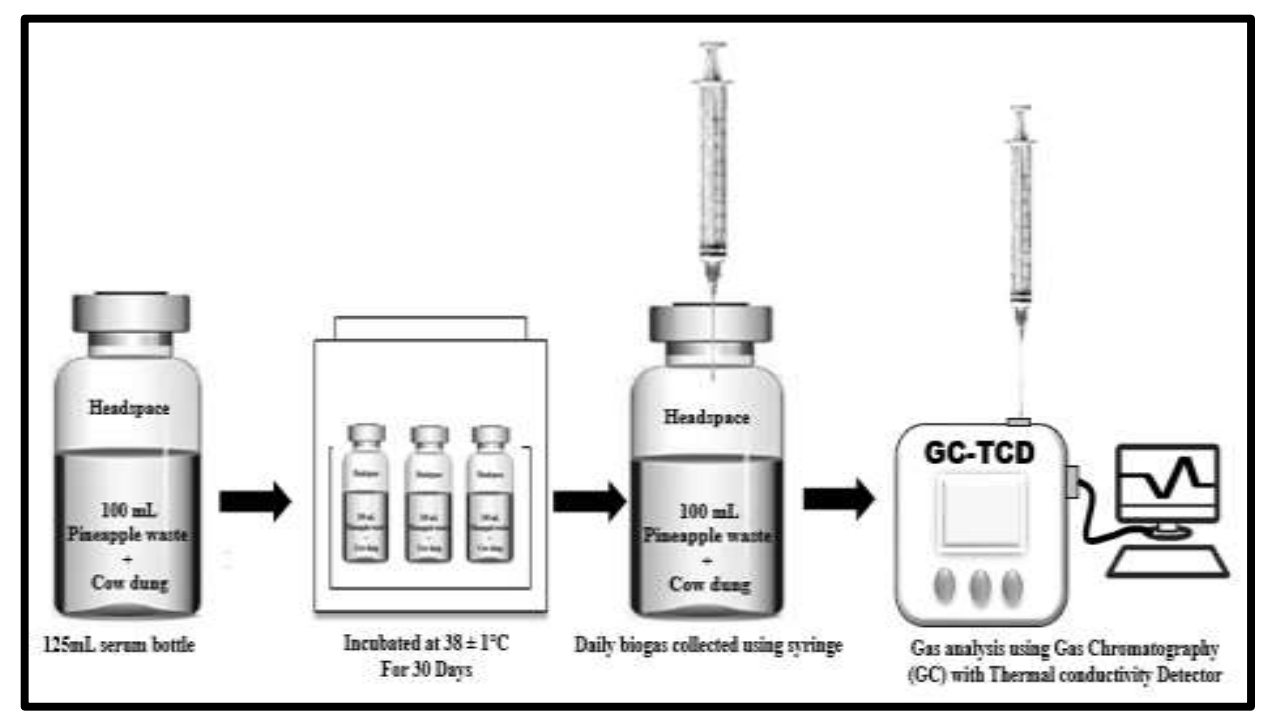

Figure 1. The co-digestion of pineapple waste and cow dung process.

\subsection{Biogas Measurement and Analysis}

The composition of the daily biogas produced was determined by a gas chromatograph (GC) (Agilent 6890) with thermal conductivity detector (TCD). Methane $\left(\mathrm{CH}_{4}\right)$ gas quantity in $1 \mathrm{ml}$ sample was calculated using Equation 1 (Alemahdi et al., 2015; Khairul et al., 2018). The methane yield was expressed as the volume of methane produced based on the initial total VS of the feedstock.

$\mathrm{CH}_{4}$ area $/ 2291.67=\mathrm{qCH}_{4}$ quantity in $1 \mathrm{ml}$ gas sample

\section{Results and Discussions}

\subsection{Characteristics of Pineapple Waste and Cow Dung}

It is crucial to examine the characteristic of the waste before conducting the codigestion process, pineapple waste and cow dung were first characterised based on their TS, VS, carbon content, nitrogen content, $\mathrm{C} / \mathrm{N}$ ratio and $\mathrm{pH}$, and the results are summarised in Table 1. It can be seen from the characterisation results, the TS, VS and $\mathrm{pH}$ of the pineapple were $79.35 \%, 4.95 \%$ and $4.82 \%$, respectively while $81.86 \%, 6.25 \%$ and $6.81 \%$ for cow dung, respectively. In accordance with that, cow dung had the highest TS, VS and pH compared to pineapple waste. Formerly, Rani and Nand (2004) reported that the TS, VS and pH of pineapple as $72.57 \%, 95.90 \%$ and $4.7 \%$ whereas Anhuradha and Mullai (2010) stated that TS and VS of cow dung were $15.32 \%$ and $77.50 \%$, respectively. High TS value suggests that there is low water content in the wastes (Ardaji et al., 2016; Liotta et al., 2014). Apart from that, pineapple waste has high carbon content compared to cow dung. The $\mathrm{C} / \mathrm{N}$ ratio of pineapple waste and cow dung were 44.95 and 55.51, respectively, in which the ratio was 
determined from the carbon and nitrogen content from the CHNS analyser. $\mathrm{C} / \mathrm{N}$ ratio in this study was relatively higher than other studies (Anhuradha \& Mullai, 2010; Arelli et al., 2018; Bardiya et al., 1996; Dahunsi, 2019). Low nitrogen value in waste contributes to the higher $\mathrm{C} / \mathrm{N}$ ratio (Arelli et al., 2018; Dahusni, 2019). Based on the literature, $\mathrm{C} / \mathrm{N}$ of anaerobic digestion should be maintained at a ratio range of $20-30$, and unsuitable $\mathrm{C} / \mathrm{N}$ ratio can contribute to the increase of total ammonia nitrogen (TAN), free ammonia or high volatile fatty acids (VFAs) accumulation (Kainthola, Kalamdhad, \& Goud, 2019). Excessive ammonia concentration inside anaerobic digester contributes to elevated $\mathrm{pH}$ in the digester, which is toxic to methanogens as well as leads to microbial growth inhibition (Rabii et al., 2019).

Table 1. Characterisation of pineapple waste and cow dung.

\begin{tabular}{ccc}
\hline Parameter & Pineapple Waste & Cow Dung \\
\hline Total Solid (TS) & $79.35 \%$ & $81.86 \%$ \\
Volatile Solid (VS) & $4.95 \%$ & $6.25 \%$ \\
Carbon content & $39.79 \%$ & $8.90 \%$ \\
Nitrogen Content & $0.89 \%$ & $0.16 \%$ \\
C/N ratio & 44.95 & 55.51 \\
pH & 4.82 & 6.81 \\
\hline
\end{tabular}

\subsection{Cumulative Biogas Production}

The cumulative biogas production for all TS at different CD: PW ratio is shown in Figure 2 (a)-(c). According to the results, the highest cumulative biogas was produced by $28 \%$ TS at 1:1 ratio of CD: $\mathrm{PW}$ followed by $28 \% \mathrm{TS}$ at $1: 3$ ratio. In contrast, the lowest cumulative biogas was produced by $12 \%$ TS at $1: 3$ ratio of the substrate. Comparing the cumulative biogas production for $12 \%, 20 \%$ and $28 \%$ at all CD: PW ratio of the substrate, $28 \%$ of TS produced the highest biogas after 30 days compared to the other TS. According to Ardaji et al. (2016), at high TS, the amount of organic matter increase could benefit the degradation process. The higher the TS percentage added, the higher the biogas produced. As observed in Figure 2(a), initially the biogas produced by $28 \%$ was lower than $20 \%$ and $12 \%$ but biogas produced kept increasing after day 3 as more substrates were degraded by the microbes. The same trends were showed by $28 \%$ TS in Figure 2 (b), where the amount of biogas produced was lower than $20 \%$ but the biogas produced was higher than all TS after day 23. Meanwhile, in 1:3 ratio as shown in Figure 2 (c), the biogas produced in $28 \%$ was always higher than all TS from the beginning until the end of the fermentation period. Even so, the composition of biogas is essential to be examined as the biogas produced contains methane and other gas components.

This finding was in accordance with those reported by Ardaji et al. (2016) who observed the effect of TS adjustment on biogas production from co-digestion of pomegranate waste, 
poultry manure and cow dung sludge. They found out that biogas production increased from $0.273 \mathrm{~L} /$ day to $0.736 \mathrm{~L} /$ day with an increase in TS from $5 \%$ to $25 \%$ and the highest TS which was $25 \%$ produced the highest biogas production. Complementary to this, it has also been reported that co-digestion of pineapple, orange, apple, banana and jackfruits produce more biogas $(975 \mathrm{ml})$ compared to pineapple alone $(900 \mathrm{ml})$ due to the high concentration of solids and total viable count of microbes than the sole fruit substrate (Chakravarty, 2016).
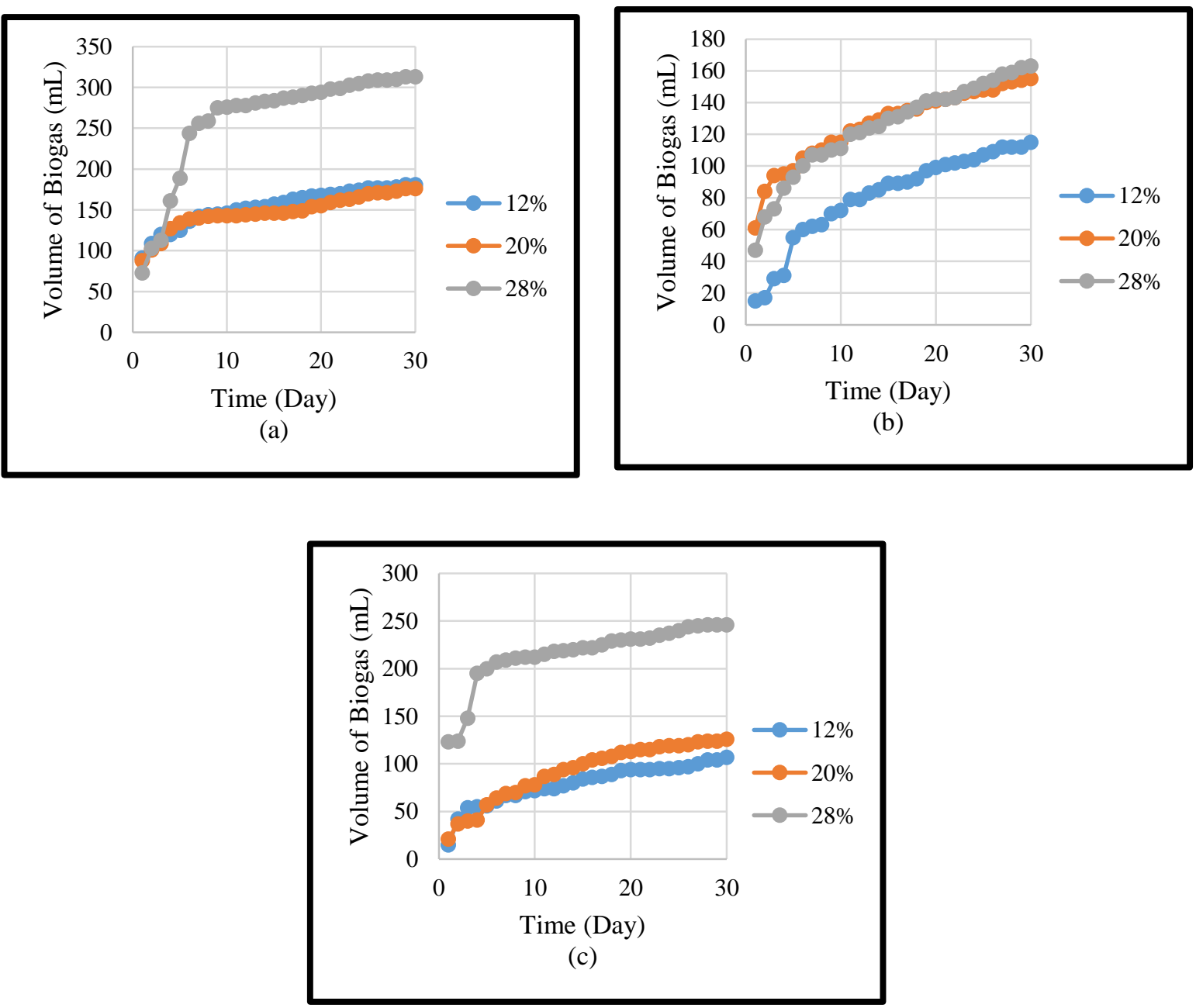

Figure 2. Cumulative biogas production for CD:PW ratio (a) $1: 1 ;$ (b) $1: 2 ;$ (c) $1: 3$.

\subsection{Methane Yield from Batch Fermentation}

The effect of TS on the cumulative methane yield at different ratio over 30 days of fermentation is shown in Figure 3 (a)-(c). According to Figure 3 (a), at 1:1 CD:PW ratio, $12 \%$ TS showed a constant increase in methane yield over 30 days of the fermentation period. Whereas at $20 \%$ and $28 \%$ TS, methane production was slower towards the end after 5 days. At 1:2 ratio CD: PW, all TS showed increasing trends in methane production (Figure 3 [b]). For $12 \%$ TS, methane produced higher methane compared to $20 \%$ and $28 \%$ TS and increased 
to the maximum yield after 5 days. Then, as illustrated in Figure 3 (c), 12\% and 20\% TS showed a constant increase. However, after 23 days, there was no methane produced for $20 \%$ TS while for $12 \%$ TS, methane was still being produced after 27 days. On the other hand, the amount of methane produced was the lowest and slow since the start for $28 \%$ TS since, at high TS, the substrate content was high in lignocellulosic materials thus making it harder for the microbes to degrade it (Abbassi-Guendouz et al., 2012; Fernández et al., 2008).
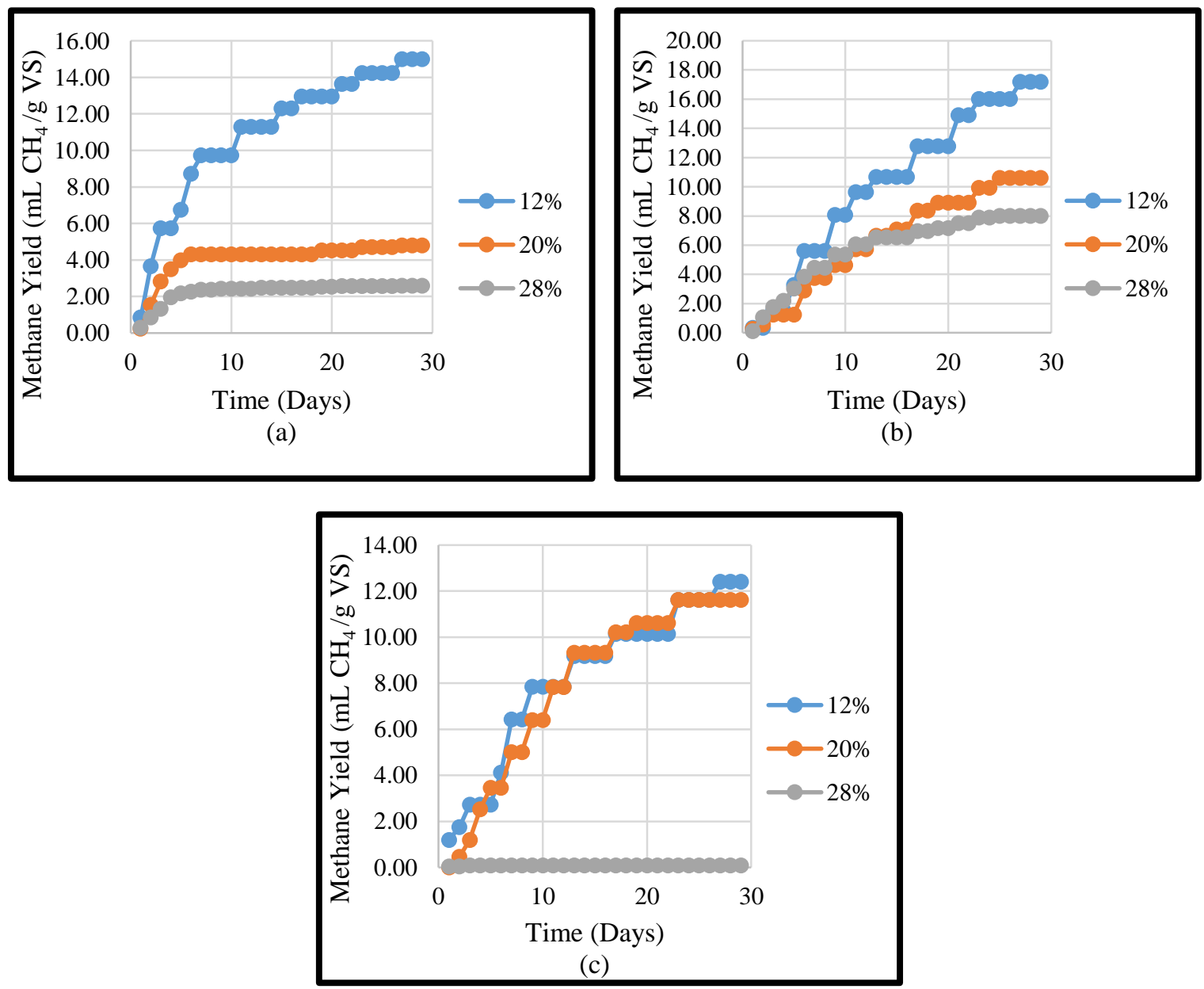

Figure 3. Cumulative methane production for CD:PW ratio (a) $1: 1 ;$ (b) $1: 2 ;$ (c) $1: 3$.

Low methane content suggests slow hydrolysis and low biodegradability of the substrate. To which at higher TS content, the amount of substrate increases while water content decreases, thus contributing to the aforementioned problems (Ardaji et al., 2016; Orhorhoro, Ebunilo \& Sadjere, 2017). High pineapple wastes in the substrate mixture also make it hard for the microbes to degrade the wastes. According to Jehan et al. (2017), a slow rate of degradation of the substrates is due to the complex structure of lignocellulosic biomass such as pineapple that makes it hard for the microbe to digest the substrate. Dahunsi (2019) also pointed out that due to the lignin-cellulose matrix in lignocellulosic biomass, there are limits in the process efficacy during hydrolysis where microbial enzymes fail to degrade these substrates. Lignin-cellulose matrix presence in the lignocellulosic wastes itself makes its 
structure very complex and resistant to deconstruction. The exposure of cellulose and hemicellulose to microbial attack during hydrolysis to convert it into simple sugar is interrupted by its cell structure support named lignin (Karuppiah \& Azariah, 2019). The lignin layer protects the cellulose and hemicellulose and makes it inaccessible for degradation.

Overall, $12 \%$ TS of 1:2 ratio CD:PW resulted in the highest methane yield with $17.19 \mathrm{ml}$ $\mathrm{CH}_{4} / \mathrm{g}$ VS followed by $12 \% \mathrm{TS}$ at $1: 1$ ratio with $15 \mathrm{ml} \mathrm{CH}_{4} / \mathrm{g}$ VS after 30 days. Conversely, the lowest methane yield was produced by $28 \%$ TS at a 1:3 ratio with only $0.08 \mathrm{ml} \mathrm{CH}_{4} / \mathrm{g}$ VS. In this study, it was observed that methane yield decreases as the TS percentage increases at all ratio in which TS of $28 \%$ contributes to the lowest methane yield at all ratio. Even if $28 \%$ TS gives the highest biogas produced compared to $12 \%$ and $20 \%$, the methane content is low. This is due to the other biogas composition such as carbon dioxide and hydrogen that contribute more in terms of its composition (Khairul et al., 2018; Neshat et al., 2017). Biogas that contains high methane makes it a useful fuel to replace natural gas or can be transformed into heat and electricity (Jafari-Sejahrood et al., 2019).

Similar findings were reported by Ogunleye et al. (2016) using animal waste and fruit wastes where the yield of methane decreased with an increase in TS content from $8 \%$ to $40 \%$. Liotta et al. (2014) also mentioned that increasing TS of food waste from $4.5 \%$ to $19.2 \%$ contributes to the reduction in methane production. The drop in methane yield as TS increases is due to the amount of water. Water reduces the restriction of mass transfer of the particulate substrate and promotes hydrolysis, making it possible for bacteria growth and movement as well as nutrient transportation (Ejiroghene et al., 2017; Liotta et al., 2014). Thus, at higher TS, low water content causes the transport process to be slower which on the other hand, reduces the level of microbial activity, hence, lowering the methane produced (Liotta et al., 2014).

\section{Conclusion}

It can be concluded that the co-digestion of pineapple waste and cow dung has proved that the addition of pineapple waste has the potential of increasing biogas. This study focused on the effect of the TS percentage on the biogas and methane yield from the co-digestion process. Co-digestion of pineapple waste at high TS content produces high biogas yield. On the contrary, high methane yield is observed at low TS percentage although, at low TS content, the amount of biogas is low. A decreasing trend of methane yield is observed when increasing the TS content. Low methane content suggests low water content at high TS which inhibits the microbial activity, thus, reducing the digestion process. Moreover, the presence of complex structure due to the lignin layer that binds cellulose and hemicellulose in pineapple wastes makes it harder for microbes to degrade the substrate and consequently slows down the hydrolysis process. Further improvement should be implemented and developed to improve the efficacy of the process such as pretreatment of pineapple waste itself and make it accessible for the microbe to degrade the wastes. Thus, it was proven that 
successful implementation of the anaerobic co-digestion as a method of waste treatment has the potential to change the concept of 'waste to wealth' which will lead to total utilisation of renewable energy resources in reducing energy requirement, making it readily available and minimising environmental pollution.

Author Contributions: Conceptualization, AFAH and FNAM; Formal analysis, AFAH and FNAM; Investigation, AFAH and FNAM; Methodology, AFAH and FNAM; Supervision, MHH, HCM, NSJ and SIS; Validation, MHH, HCM, NSJ and SIS; Writing - original draft, AFAH; Writing — review \& editing, MHH and HCM All authors have read and agreed to the published version of the manuscript.

Funding: This research was financially supported by Geran Putra — Inisiatif Putra Muda (GP-IPM) through Universiti Putra Malaysia Grant (Grant No: GP-IPM/2018/9669700).

Acknowledgments: Thanks and appreciation are acknowledged to the Department of Biological and Agricultural Engineering, Department of Chemical and Environmental Engineering and Smart Farming Technology Research Centre, Faculty of Engineering, Universiti Putra Malaysia, Selangor, Malaysia.

Conflicts of Interest: The authors declare that there is no conflict of interest in this work.

\section{References}

Abbassi-Guendouz, A., Brockmann, D., Trably, E., et al. (2012). Total solids content drives high solid anaerobic digestion via mass transfer limitation. Bioresource Technology, 111, 55-61. https://doi.org/10.1016/j.biortech.2012.01.174

Alemahdi, N., Che Man, H., Abd Rahman, N., et al. (2015). Enhanced mesophilic bio-hydrogen production of raw rice straw and activated sewage sludge by co-digestion. International Journal of Hydrogen Energy, 40(46), 16033-16044. https://doi.org/10.1016/j.ijhydene.2015.08.106

Anhuradha, S. \& Mullai, P. (2010). Mesophilic biodigestion of cowdung and mango peel in relation to bioenergy-batch study. An Indian Journal, 5(5), 320-324.

Ardaji, V., Radnezhad, H. \& Nourouzi, M. (2016). Improving biogas production performance from pomegranate waste, poultry manure and cow dung sludge using thermophilic anaerobic digestion: Effect of total solids adjustment. Journal of Earth, Environment and Health Sciences, 2(3), 97. https://doi.org/10.4103/2423-7752.199293

Arelli, V., Begum, S., Anupoju, G. R. et al. (2018). Dry anaerobic co-digestion of food waste and cattle manure: Impact of total solids, substrate ratio and thermal pre treatment on methane yield and quality of biomanure. Bioresource Technology, 253, 273-280. https://doi.org/10.1016/j.biortech.2018.01.050

Astals, S., Nolla-Ardèvol, V. \& Mata-Alvarez, J. (2013). Thermophilic co-digestion of pig manure and crude glycerol: Process performance and digestate stability. Journal of Biotechnology, 166(3), 97-104. https://doi.org/10.1016/j.jbiotec.2013.05.004

Bardiya, N., Somayaji, D., \& Khanna, S. (1996). Biomethanation of banana peel and pineapple waste. Bioresource Technology, 58(1), 73-76. https://doi.org/10.1016/S0960-8524(96)00107-1

Chakravarty, G. (2016). Evaluation of fruit wastes as substrates for the production of biogas. Scholars Research Library Annals of Biological Research, 7(3), 25-28. Retrieved from http://scholarsresearchlibrary.com/archive.html

Chan, Y. K. (2000). Status of the pineapple industry and research and development in Malaysia. Acta Horticulturae, 529 , 77-83. https://doi.org/10.17660/actahortic.2000.529.7

Chu, M. M. (2019, July). Generating more waste than ever. The Star Online. Retrieved from https://www.thestar.com.my/news/nation/2019/07/30/generating-more-waste-than-ever\#1cbSCyx1wuM8MyGX.99

Dahunsi, S. O. (2019). Liquefaction of pineapple peel: Pretreatment and process optimization. Energy, 185, $1017-1031$. https://doi.org/10.1016/j.energy.2019.07.123 
Deressa, L., Libsu, S., Chavan, R. B., et al. (2015). Production of biogas from fruit and vegetable wastes mixed with different wastes. Environment and Ecology Research, 3(3), 65-71. https://doi.org/10.13189/eer.2015.030303

Elina, T. (2016). Utilization of Food Waste via Anaerobic Digestion. Tampere,Findland: Tampere University of Technology.

Fernández, J., Pérez, M. \& Romero, L. I. (2008). Effect of substrate concentration on dry mesophilic anaerobic digestion of organic fraction of municipal solid waste (OFMSW). Bioresource Technology, 99(14), 6075-6080. https://doi.org/10.1016/j.biortech.2007.12.048

Giuliano, A., Bolzonella, D., Pavan, P., et al. (2013). Co-digestion of livestock effluents, energy crops and agro-waste: Feeding and process optimization in mesophilic and thermophilic conditions. Bioresource Technology, 128, 612618. https://doi.org/10.1016/j.biortech.2012.11.002

Gupta, K. K., Aneja, K. R., \& Rana, D. (2016). Current status of cow dung as a bioresource for sustainable development. Bioresources and Bioprocessing, Vol. 3, pp. 1-11. https://doi.org/10.1186/s40643-016-0105-9

Hagos, K., Zong, J., Li, D., et al. (2017). Anaerobic co-digestion process for biogas production: Progress, challenges and perspectives. Renewable and Sustainable Energy Reviews, 76, 1485-1496. https://doi.org/10.1016/j.rser.2016.11.184

Jafari-Sejahrood, A., Najafi, B., Faizollahzadeh Ardabili, S., et al. (2019). Limiting factors for biogas production from cow manure: energo-environmental approach. Engineering Applications of Computational Fluid Mechanics, 13(1), 954966. https://doi.org/10.1080/19942060.2019.1654411

Jehan, O. S., Sanusi, S. N. A., Sukor, M. Z., et al. (2017). Biogas production from pineapple core - A preliminary study. AIP Conference Proceedings, 1885(1), 020246. https://doi.org/10.1063/1.5002440

Kainthola, J., Kalamdhad, A. S., \& Goud, V. V. (2019). Optimization of methane production during anaerobic co-digestion of rice straw and hydrilla verticillata using response surface methodology. Fuel, 235, 92-99. https://doi.org/10.1016/j.fuel.2018.07.094

Karuppiah, T. \& Azariah, V. E. (2019). Biomass pretreatment for enhancement of biogas production. Anaerobic Digestion. https://doi.org/10.5772/intechopen.82088

Khai Lun, O., Bee Wai, T. \& Siew Ling, L. (2014). Pineapple cannery waste as a potential substrate for microbial biotranformation to produce vanillic acid and vanillin. International Food Research Journal, 21.

Khairul Anuar, N., Che Man, H., Idrus, S. et al. (2018). Biochemical methane potential (BMP) from anaerobic co-digestion of sewage sludge and decanter cake. IOP Conference Series: Materials Science and Engineering, 368(1), 012027. https://doi.org/10.1088/1757-899X/368/1/012027

Liotta, F., D’Antonio, G., Esposito, G., et al. (2014). Effect of total solids content on methane and volatile fatty acid production in anaerobic digestion of food waste. Waste Management and Research, 32(10), 947-953. https://doi.org/10.1177/0734242X14550740

Maneeintr, K., Leewisuttikul, T., Kerdsuk, S., et al. (2018). Hydrothermal and enzymatic treatments of pineapple waste for energy production. Energy Procedia, 152, 1260-1265. https://doi.org/10.1016/j.egypro.2018.09.179

Mata-Alvarez, J., Macé, S., \& Llabrés, P. (2000). Anaerobic digestion of organic solid wastes. An overview of research achievements and perspectives. Bioresource Technology, 74(1), 3-16. https://doi.org/10.1016/S09608524(00)00023-7

Neshat, S. A., Mohammadi, M., Najafpour, G. D. et al. (2017). Anaerobic co-digestion of animal manures and lignocellulosic residues as a potent approach for sustainable biogas production. Renewable and Sustainable Energy Reviews, 79, 308-322. https://doi.org/10.1016/j.rser.2017.05.137 
Ogunleye, O. O., Aworanti, O. A., Agarry, S. E., et al. (2016). Enhancement of animal waste biomethanation using fruit waste as co-substrate and chicken rumen as inoculums. Energy Sources, Part A: Recovery, Utilization and Environmental Effects, 38(11), 1653-1660. https://doi.org/10.1080/15567036.2014.933286

Orhorhoro, E. K., Ebunilo, P. O., \& Sadjere, G. E. (2017). Experimental determination of effect of total solid (ts) and volatile solid (vs) on biogas yield. American Journal of Modern Energy, 3(6), 131-135. https://doi.org/10.11648/j.ajme.20170306.13

Rabii, A., Aldin, S., Dahman, Y., et al. (2019). A review on anaerobic co-digestion with a focus on the microbial populations and the effect of multi-stage digester configuration. Energies, 12(6). https://doi.org/10.3390/en12061106

Rani, D. S. \& Nand, K. (2004). Ensilage of pineapple processing waste for methane generation. Waste Management, 24(5), 523-528. https://doi.org/10.1016/j.wasman.2003.10.010

Sibiya, N. T., Muzenda, E., \& Tesfagiorgis, H. B. (2014). Effect of temperature and $\mathrm{pH}$ on the anaerobic digestion of grass silage. 6th International Conference on Green Technology, Renewable Energy and Environmental Engineering, 2728.

Yi, J., Dong, B., Jin, J., et al. (2014). Effect of increasing total solids contents on anaerobic digestion of food waste under mesophilic conditions: Performance and microbial characteristics analysis. PLoS ONE, 9(7). https://doi.org/10.1371/journal.pone.0102548

Copyright $($ ) 2020 by Aili Hamzah AF, et al. and HH Publisher. This work is licenced under the Creative

Commons Attribution-NonCommercial 4.0 International Licence (CC-BY-NC4.0) 